\title{
Transfer IPTEK Bahaya penyalahgunaan Obat pada Remaja dan pencegahannya di Pondok Muqorrobin Jalan Raya Brangkal- Mojokerto
}

\author{
Yufi Aris Lestari, Riska Aprilia Wardani*, Kurnia Indriyanti P.S \\ Sekolah Tinggi Ilmu Kesehatan Dian Husada Mojokerto \\ *Correspondent Author: riezwea@yahoo.com
}

\begin{abstract}
ABSTRAK
Dinas Kesehatan (Dinkes) Jatim dan Badan Nasional Narkotika (BNN) Jatim menunjukan bahwa jumlah mencapai 238.680 orang atau 27,3 persen dari pengguna narkoba Jatim sebanyak 884.000 orang (Jatim newaroom, 2017). Badan Narkotika Nasional Kota (BNNK) Surabaya, menemukan peningkatan penyalahgunaan narkoba dalam dua tahun terakhir. Di tahun 2016 di temukan 84 pelajar di kota surabaya menjadi pengguna narkoba dan sedang menjalani proses rehabilitasi. Dari jumlah itu menunjukan peningkatan pada tahun 2017 yaitu 101 pelajar dengan kecanduan narkoba dan pil dobel L. Kebanyakan dari mereka adalah pelajar dari 4 SD, 63 SMP, 34 SMA (Jatimtimes,Surabaya 2018).

Semakin meningkatnya penyalahgunaan napza dikalangan remaja di sebabkan oleh faktor-faktor pencetus seperti depresi, kegagalan dalam pencapaian harapan, kondisi fisik, psikologis, sedangkan untuk faktor pendukung diantaranya: perpisahan orang tua, pengaruh lingkungan sekitar dan sekolah, gaya pergaulan, adanya pembulian, dan pengaruh teman sebaya. Remaja merupakan usia rentan terpengaruhi oleh hal baru tidak terkecuali rasa ingin tahu mengenai banyak hal yang menurutnya menarik untuk di coba, seperti (alkohol, sabu, narkoba, obat/pil terlarang). Mereka menganggap bahwa dengan mengonsumsi itu semua kan membuatnya merasakan sensasi seperti fly atau melayang dan menghilangkan sedikit pikiran dalam otak yang selama ini menumpuk. Pencegahan pengguna napza pada remaja sebagian besar bias dilakukan dengan menggunakan mekanisme koping yang positif antara lain olahraga, bercanda, dan bercerita.

Untuk meningkatkan kemampuan mekanisme koping pada remaja dibutuhkan sosialisasi yang maksimal, sehingga dapat menggunakan mekanisme koping yang benar dalam pengambilan keputusan suatu permasalahan.
\end{abstract}

Kata Kunci: Remaja, Mekanisme Koping, Napza

\section{PENDAHULUAN}

Depresi merupakan hilangnya perasaan kendali dan pengalaman seseorang yang mengalami penderitaan berat, maupun emosional. Mekanisme koping menjadi cara yang digunakan oleh individu dalam menyelesaikan masalah, mengatasi perubahan yang terjadi baik secara kognitif maupun perilaku. Napza terdiri dari zat atau obat yang berasal dari tanaman atau bukan tanaman, baik sintesis maupun semisintesis, yang dapat menyebabkan penurunan atau perubahan kesadaran, hilangnya rasa nyeri dan dapat menimbulkan ketergantungan.

Dinas Kesehatan (Dinkes) Jatim dan Badan Nasional Narkotika (BNN) Jatim menunjukan bahwa jumlah mencapai 238.680 orang atau 27,3 persen dari pengguna narkoba Jatim sebanyak 884.000 orang (Jatim newaroom, 2017). Badan Narkotika Nasional Kota (BNNK) Surabaya, menemukan peningkatan penyalahgunaan narkoba 


\section{Journal of Community Engagement in Health}

http://jceh.org

https://doi.org/10.30994/jceh.v4i2.256

ISSN: 2620-3758 (print); 2620-3766 (online)

Vol. 4 No 2. Sep 2021. Page. 383-387

dalam dua tahun terakhir. Di tahun 2016 di temukan 84 pelajar di kota surabaya menjadi pengguna narkoba dan sedang menjalani proses rehabilitasi. Dari jumlah itu menunjukan peningkatan pada tahun 2017 yaitu 101 pelajar dengan kecanduan narkoba dan pil dobel L. Kebanyakan dari mereka adalah pelajar dari 4 SD, 63 SMP, 34 SMA (Jatimtimes,Surabaya 2018).

Semakin meningkatnya penyalahgunaan napza dikalangan remaja di sebabkan oleh faktor-faktor pencetus seperti depresi, kegagalan dalam pencapaian harapan, kondisi fisik, psikologis, sedangkan untuk faktor pendukung diantaranya: perpisahan orang tua, pengaruh lingkungan sekitar dan sekolah, gaya pergaulan, adanya pembulian, dan pengaruh teman sebaya. Remaja merupakan usia rentan terpengaruhi oleh hal baru tidak terkecuali rasa ingin tahu mengenai banyak hal yang menurutnya menarik untuk di coba, seperti (alkohol, sabu, narkoba, obat/pil terlarang). Mereka menganggap bahwa dengan mengonsumsi itu semua kan membuatnya merasakan sensasi seperti fly atau melayang dan menghilangkan sedikit pikiran dalam otak yang selama ini menumpuk. Pencegahan pengguna napza pada remaja sebagian besar bias dilakukan dengan menggunakan mekanisme koping yang positif antara lain olahraga, bercanda, dan bercerita.

\section{METODE}

\section{Survei lapangan}

Survei lapangan bertujuan untuk mengamati situasi dan keadaan pondok Muqorrobin tersebut yang direncanakan sebagai objek sasaran.

\section{Menentukan Sasaran}

Sasaran program yaitu remaja di pondok Muqorrobin di desa Gemekan kecamatan Sooko Kabupaten Mojokerto.

\section{Koordinasi}

Berkoordinasi dengan pihak pengurus pondok Muqorrobin untuk menentukan kesepakatan mufakat antara pelaksana program dengan sasaran program.

\section{Sosialisasi Program}

Sosialisasi program bertujuan untuk memberikan informasi mengenai rencana serangkaian pelaksanaan program yang disampaikan kepada pengurus pondok Muqorrobin desa Gemekan Kecamatan Sooko Kabupaten Mojokerto.

\section{Pelaksanaan Program}

Kegiatan pelayanan kesehatan kepada remaja di pondok Muqorrobin disampaikan oleh tim pelaksana kegiatan dan dilanjutkan dengan sosialisasi mengenai dampak penyalahgunaan obat. Evaluasi yang dilakukan jugabertujuan untuk mengetahui pemahaman remaja tentang Napza dan untuk mengetahui kendala yang dialami oleh mitra pengabdian masyarakat dan upaya yang dapat ditempuh oleh tim pelaksana kegiatan untuk mengatasi permasalahan yang terjadi sehingga output dari pelaksanaan kegiatan pengabdian masyarakat sesuai dengan tujuan dan dapat berlanjut sesuai dengan tujuan kegiatan pengabdian masyarakat. 


\section{HASIL}

1. Tingkat pemahaman remaja tentang Napza baik sebanyak 25 responden $(78.1 \%)$, dan sebagian kecil responden dengan pemahaman cukup sebanyak 7 orang $(21.9 \%)$.

2. Tingkat pemahaman remaja tentang Mekanisme koping remaja di pondok Muqorrobin di dapatkan sebagian besar responden tergolong dalam pemahaman yang baik ttg mekanisme koping maladaptif sebanyak 21 responden $(65.6 \%)$, dan hampir setengahnya responden yang tergolong dalam pemahaman cukup mekanisme koping adaptif sebanyak 11 responden (34.4\%).

\section{PEMBAHASAN}

Semakin meningkatnya penyalahgunaan napza dikalangan remaja di sebabkan oleh faktor-faktor pencetus seperti depresi, kegagalan dalam pencapaian harapan, kondisi fisik, psikologis, sedangkan untuk faktor pendukung diantaranya: perpisahan orang tua, pengaruh lingkungan sekitar dan sekolah, gaya pergaulan, adanya pembulian, dan pengaruh teman sebaya. Remaja merupakan usia rentan terpengaruhi oleh hal baru tidak terkecuali rasa ingin tahu mengenai banyak hal yang menurutnya menarik untuk di coba, seperti (alkohol, sabu, narkoba, obat/pil terlarang). Mereka menganggap bahwa dengan mengonsumsi itu semua kan membuatnya merasakan sensasi seperti fly atau melayang dan menghilangkan sedikit pikiran dalam otak yang selama ini menumpuk. Pencegahan pengguna napza pada remaja sebagian besar bias dilakukan dengan menggunakan mekanisme koping yang positif antara lain olahraga, bercanda, dan bercerita. Untuk meningkatkan kemampuan mekanisme koping pada remaja dibutuhkan sosialisasi yang maksimal, sehingga dapat menggunakan mekanisme koping yang benar dalam pengambilan keputusan suatu permasalahan.

\section{KESIMPULAN}

Kesimpulan dari program ini yaitu Pencegahan pengguna napza pada remaja sebagai mitra pengabdian masyarakat dilakukan dengan menggunakan mekanisme koping yang positif antara lain dengan olahraga, bercanda, dan bercerita. Peningkatan pengetahuan dan pemahaman yang dimiliki oleh mitra pengabdian masyarakat tentang bahaya penggunaan NAPZA.

\section{UCAPAN TERIMA KASIH}

Ucapan terima kasih kami sampaikan kepada segenap pihak yang membantu pelaksanaan kegiatan pengabdian kepada masyarakat ini antara lain : kepada para mitra serta remaja yang ada di pondok muqorrobin yang telah membantu pelaksanaan pengabdian masyarakat ini. 


\section{Journal of Community Engagement in Health}

http://jceh.org

ISSN: 2620-3758 (print); 2620-3766 (online)

https://doi.org/10.30994/jceh.v4i2.256

Vol. 4 No 2. Sep 2021. Page. 383-387

\section{REFERENSI}

Ali, M dan Asrori, M. 2009. Psikologi Remaja, Perkembangan Peserta Didik. Jakarta: Bumi Aksara

Al-Mighwar, M. 2009. Psikologi Remaja. Bandung:CV Pustaka Setia

Beck, A. T. (2006). Depression: Causes and Treatment. Philadelphia: University of Pennsylvania Press.

Dahlan, M. S. 2011. Statistik untuk kedokteran dan kesehatan. Jakarta: Salemba Medika

Dedi humas, "faktor penyebab penyalahgunaan narkotika". Sumber: http://dedihumas.bnn.go.id/read/section/artikel/3013/07/23/704/faktor-penyebabpenyalahgunaan-narkotika (diakses 25 november 2018, jam 15.25 am)

Depkes RI, 2010. The World Health Report 2009. http://www.litbang.depkes.go.id I diakses 26 november 2018]

Handayani, S. (2011). Pengaruh Keluarga, Masyarakat, dan Pendidikan Terhadap Pencegahan Bahaya Narkoba Dikalangan Remaja. (Tesis). Jakarta: Salemba Medika

Hidayat. A. Aziz Alimul. 2011. Pengantar Konsep Dasar Keperawatan. Jakarta: Salemba Medika

Kaplan H.I, Sadock B.J, Grebb J.A. 2010. Sinopsis Psikiatri jilid 2. Terjemahan Widjaja Kusuma. Jakarta: Binarupa Aksara. p. 17-35

Keliat B. A. 2010. Proses Keperawatan Kesehatan Jiwa. $5^{\text {th }}$ ed. Jakarta: ECG

Maslim, R. (2011). Diagnosa Gangguan Jiwa Rujukan Ringkas PPDGJ-III. Jakarta: PT. Nuh Jaya.

Mustikasari. 2009. Mekanisme Koping. Penprofil (Pendidikan, Profesi dan Ilmiah) Bem Km Fkep UNAND. Jakarta : Penerbit Rineka Cipta

Nasir, A., dan Muhith, A. (2011). Dasar-dasar Keperawatan Jiwa: Pengantar dan Teori. Jakarta: Salema Medika.

National Institute Mental Health (NIMH) Journal description. (2010). Depression .

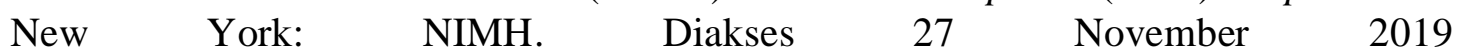
https://www.nimh.nih.gov/health/topics/depression/major-depression-amongaduls.shtml.

Rahmadona, E., Agustin, H. (2014). Faktor yang berhubungan dengan penyalahgunaan narkoba di RSJ Prof. HB. Sa'anin. Jurnal Kesehatan Masyarakat Andalas, 8(2),59-65. Diakses 26 november 2018 dari http://jurnal.fkm.unand.ac.id

Rasmun, 2010. Stres, Koping dan Adaptasi. Jakarta: Sagung Seto

Safaria, T. (2009). Kecenderungan penyalahgunaan napza ditinjau dari tingkat religiusitas, regulasi emosi , motif berprestasi , harga diri , keharmonisan keluarga dan 


\section{Journal of Community Engagement in Health}

pengaruh negatif teman sebaya.Humanitas, 4(1),13-24. Diakses dari http://journal.uad.ac.id/index.php

Sajiah, Tisa Siti. 2017 Pengaruh Kecerdasan Emosi dan Strategi koping terhadap Resilliensi Remaja Korban Penyalahgunaan Narkoba Di panti Rehabilitasi. Skripsi.Bogor: Institusi Pertanian Bogor.

Santrock, J.W (2013). Psikologi Pendidikan. Edisi 5 Buku 2. Terjemahan Tri Wibowo B.S. Jakarta : Salemba Humanika

Sarafino, E. P. 2013. Health psychology, biospsychosocial Interaction New York: Mc Graw Hill Inc

Setiadi, (2012). Konsep dan Penulisan Riset Keperawatan. Yogyakarta: Graha Ilmu

Stuart, G. W. 2013. Buku Saku Keperawatan Jiwa, Edisi 5. Alih Bahasa Oleh Ramona P. Dan Egi Kayama. Jakarta: EGC

Suprapto, 2009. Komunikasi Organisasi, Jakarta : Edisi V. Cetakan ketujuh

Suryani, E. Dan H. Widyasih. 2009. Psikologi ibu dan anak. Yogyakarta Fitramaya 